\title{
Ozonation of return activated sludge for disintegration and solubilisation with synthesized titanium oxide as catalyst
}

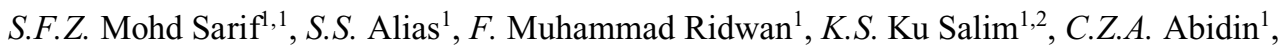 \\ and U.F. Md. Ali ${ }^{1}$ \\ ${ }^{1}$ School of Environmental Engineering, Kompleks Pusat Pengajian Jejawi 3, Universiti Malaysia \\ Perlis, 02600 Arau Perlis, Malaysia \\ ${ }^{2}$ Shorubber (M) SDN. BHD, No 2, Jalan Perindustrian Ringan 6, Kawasan Perindustrian Jejawi, Arau \\ 02600 Perlis, Malaysia
}

\begin{abstract}
Ozonation of activated sludge in the present of titanium dioxide $\left(\mathrm{TiO}_{2}\right)$ as catalyst to enhance the production of hydroxyl radical was evaluated in comparison to the sole ozonation process. In this process, the catalytic ozontion showed improvement in increasing ozone consumption and improving activated sludge disintegration and solubilisation. The reduction of total suspended solid (TSS), volatile suspended solid (VSS) and soluble chemical oxygen demand (SCOD) solubilisation was better in the catalytic ozonation system. Initial $\mathrm{pH} 7$ of activated sludge was found best to disintegrate and solubilise the sludge flocs. However upon additional of sodium hydroxide $(\mathrm{NaOH})$ in $\mathrm{pH}$ adjustment enhanced the solubilisation of organic matter from the flocs and cells, making the initial $\mathrm{pH} 9$ is the best condition for activated sludge solubilisation. Yet the initial $\mathrm{pH} 7$ of activated sludge supernatant was the best condition to achieve SCOD solubilisation due to sludge floc disintegration, when it had stronger correlation between TSS reduction and SCOD solubilisation $\left(\mathrm{R}^{2}=0.961\right)$. Lower amount of catalyst of $100 \mathrm{mgTiO}_{2} / \mathrm{gTSS}$ was found to disintegrate and solubilise the activated sludge better with $30.4 \%$ TSS reduction and $25.2 \%$ SCOD solubilisation efficiency, compared to 200 $\mathrm{mgTiO}_{2} / \mathrm{gTSS}$ with $21.9 \%$ and $17.1 \%$ TSS reduction and SCOD solubilisation, respectively.
\end{abstract}

\section{Introduction}

The activated sludge is a biological process involves microorganism in organic pollutant degradation in the wastewater [1]. Domestic and industrial wastewater treatment system adopted this method in organic pollutant degradation because of high efficiency. Despite the good performance, it produced a large volume of waste in the end of the process, which requires $65 \%$ from the total plant operation cost for treatment and disposal [2]. Therefore such research has been conducted involves lysis-cryptic growth to reduce the sludge production and increase organic matter solubilisation in water line, for example by means

\footnotetext{
* Corresponding author: msfatimahzahra@gmail.com
} 
of biological sludge worm [3], chemical oxidation by potassium permanganate [4] and ultrasonic [5].

The lysis-cryptic growth occurs in biological system, however the cell lysis is hard to achieve and become the rate limiting step in the process. Therefore, the following process of cryptic growth and degradation of organic pollutant is retarded. Lysis is a process to break the sludge cell so that the intracellular organic matter solubilised in supernatant and became the food source for endogenous bacteria, while part of it will be oxidized into water and carbon dioxide. Meanwhile the cryptic growth is the growing of new cell from the soluble substrate [6]. The damage sludge structure and cell contribute to reduction volume of the activated sludge.

Ozone is a powerful oxidant with potential of $2.07 \mathrm{eV}$ makes it popular in colour improvement, organic and inorganic removal from wastewater [7]. However, ozone is very selective and unable to oxidize certain organic compounds (e.g. natural organic compound) [8] and small molecular organic acids such as acetic acid, oxalic acid, and glyoxalic acid [9, 10]. The ozonation process in aqueous solution may occur in two routes: direct route is when the reaction by molecular ozone, and/or indirect route which the reaction of $\mathrm{OH} \bullet$ involves. The efficiency of disintegration and solubilisation of activated sludge is expected to be higher due to the presence of more $\mathrm{OH} \bullet$, the powerful oxidant $(2.33 \mathrm{eV})$ [8].

The promotion to generate more $\mathrm{OH} \bullet$ in oxidation process is called the advanced oxidation process [8]. One of a method to enhance the production of $\mathrm{OH} \bullet$ by ozone decomposition is using solid metal as catalyst. The catalyst provides more active sites on the surface for the molecular ozone to adsorb and decompose into $\mathrm{OH} \bullet$. Such metal oxide has been used in ozonation process like $\mathrm{TiO}_{2}$ [11], $\mathrm{MnO}_{2}$ [12] and $\mathrm{ZnO}$ [13]. Of all, $\mathrm{TiO}_{2}$ has the advantages of higher stability, lower production cost [14] and harmless to living issue [15]. The good performance showed in removing organic contaminants from river water [16], degradation of nitrobenzene [17] and atrazine [18].

Up to this paper is written, the only study focusing on sludge reduction was conducted by Lee et al. using various metal ions, and $\mathrm{Mn}$ ion with ball mill for sewage sludge reduction $[19,20]$. Utilizing metal ions (homogeneous catalyticozonation) caused the ions to stay in water and therefore, increase the secondary pollutant [21] and require additional treatment to remove, which is impractical [22]. Therefore utilizing solid metal as catalyst in ozonation process is preferable to degrade and mineralize the organic pollutant with high efficiency yet low negative effect [23].

Since there are lack of study embarking the activated sludge ozonation withmetaloxidecatalyst to enhance disintegration and solubilisation, this research was conducted to fill this gap. The efficiency of activated sludge disintegration and solubilisation in ozonation process with and without catalyst was compared. Synthesized catalyst namely $\mathrm{TiO}_{2}$ was used for this purpose. The efficiency of catalytic ozonation (CO) is greatly depends on catalyst and solution $\mathrm{pH}$ [8], so this research was conducted to evaluate the performance of activated sludge ozonation with catalyst at different dose and initial $\mathrm{pH}$.

\section{Materials and methods}

\subsection{Sample collection}

The activated sludge sample was collected from a rubber glove processing manufacturing in Arau, Perlis, Malaysia (Shorubber (M) SdnBhd) which adopted extended activated sludge process for the wastewater treatment. The activated sludge was taken from the return activated sludge (RAS) line using high density polyethylene (HDPE) bottle. Sample 
was stored in a refrigerator at $6^{\circ} \mathrm{C} \pm 1$ until further usage. The initial characteristics of raw activated sludge were $7.78 \pm 0.4 \mathrm{~g} / \mathrm{L}, 6.27 \pm 0.3 \mathrm{~g} / \mathrm{L}, 60.5 \pm 3.2 \mathrm{mg} / \mathrm{L}$ and $7565 \pm 469 \mathrm{mg} / \mathrm{L}$ for TSS, VSS, SCOD and TCOD respectively. The SSV was $973 \pm 2.02 \mathrm{~mL} / \mathrm{L}$ and $\mathrm{pH}$ was $8.09 \pm 0.2$.

\subsection{Catalyst preparation}

The catalyst was prepared according to Karami [24] and Yang et al. [17]with a little modification. Tertabutylorthothitanate $\left(\mathrm{C}_{16} \mathrm{H}_{36} \mathrm{O}_{4} \mathrm{Ti}\right)$ as precursor was mixed with ethanol and deionised water at room temperature with volumetric ratio of 1:4:0.5. The mixture was stirred to obtain dry-gel form. Then it was dried at $105{ }^{\circ} \mathrm{C}$ for 4 hours, before calcined at $500{ }^{\circ} \mathrm{C}$ for 6 hours to obtain dry powder. The pHpzc of catalyst was measured by Drift Methods, as according toBenhebal et al. [25]. Crystal size, lattice structure and phase were determined by XRD (Model Bruker D2 Phaser) in fast scan range from $10-80^{\circ}$, with $\mathrm{Cu}-$ $\mathrm{K} \alpha$ radiation $(30 \mathrm{kV}, 10 \mathrm{~mA})$ and analyzed by DIFFRAC.EVA Software.

\subsection{Ozonation experiment}

The ozonation process was conducted in a capped cylindrical glass reactor with $80 \mathrm{~mm}$ diameter and $500 \mathrm{~mm}$ height. $1200 \mathrm{~mL}$ of working activated sludge was stirred with magnetic stirrer throughout the experiment for homogeneity. An ozone reactor (A2Z Model Z-3G) was used to generate ozone with $99 \%$ purified oxygen inflow of $2 \mathrm{~L} / \mathrm{min}$. A porous fritted glass diffuser was used to allow ozone gas to flow into the reactor. The ozonation was run for maximum of 170 minutes. $100 \mathrm{~mL}$ of activated sludge sample was withdrawn from the sampling port for analysis at different interval time, and another $100 \mathrm{~mL}$ of raw sample was return into the reactor to maintain its concentration and working volume [26]. Residual ozone coming out from the reactor was trapped with $2 \%$ potassium iodide. The oxygen was kept flowing after ozonation for 3 minutes to remove trapped ozone in the tubes and reactor. Initial $\mathrm{pH}$ of 5,7 and 9 was used to study the effect of initial $\mathrm{pH}$ on catalytic ozonation performance. For effect of catalyst dosage, 100 and $200 \mathrm{mgTiO} / 2 / \mathrm{gTSS}$ was used and conducted at original $\mathrm{pH}$ of the sludge. Unless stated, the dosage for catalyst was $200 \mathrm{mg} / \mathrm{gTSS}$ for the experiments.

\subsection{Sample analysis}

TSS and VSS concentration was measured according to Standard Method [27]. Filtered supernatant was used to measure the SCOD concentration meanwhile the unfiltered sample for TCOD. The COD sample was prepared by Closed Reflux Method according to the Standard Method. The concentration was measured using a spectrophotometer (HACH 2800). HI $2211 \mathrm{pH}$ meter (HANNA Instrument) was used to measure the $\mathrm{pH}$ of activated sludge. Iodometry Method was adopted to measure ozone concentrations in aqueous solution(APHA, 1995). The calculations were as per equations below, where $24=$ conversion factor $((24000 \mathrm{me} / \mathrm{L}) /(1000 \mathrm{~mL} / \mathrm{L})), \mathrm{V}_{\mathrm{t}}=$ volume of titrated $\mathrm{Na}_{2} \mathrm{~S}_{2} \mathrm{O}_{3}(\mathrm{~mL}), \mathrm{N}$ $=$ normality of $\mathrm{Na}_{2} \mathrm{~S}_{2} \mathrm{O}_{3}(\mathrm{mg} / \mathrm{me}), \mathrm{V}_{\text {sludge }}=$ sludge working volume $(\mathrm{L})$ and $\mathrm{SS}_{\mathrm{i}}=$ initial concentration of suspended solid.

$$
\begin{aligned}
& \text { Ozone concentration }(\mathrm{mg})=24 \times \mathrm{V}_{\mathrm{t}} \times \mathrm{N} \\
& \text { Ozone dose }\left(\mathrm{mgO}_{3} / \mathrm{mgSS}\right)=\frac{\text { Mass of } \mathrm{O} 3(\mathrm{mg})}{\text { Vsludge } \times \mathrm{SSi}}
\end{aligned}
$$


Sludge disintegration efficiency was measured by the difference of TSS before and after ozonation. Solubilisation efficiency was calculated by dividing the difference SCOD concentration with the initial TCOD [28].

\section{Results and discussions}

\subsection{Catalyst characterization}

The synthesized $\mathrm{TiO}_{2}$ was estimated by the DIFFRAC.EVA Software to be in size of 64.4 $\mathrm{nm}$ and tetragonal lattice structure. There were 6 diffraction peaks matched with anatase and rutile phases. The anatase peaks were 25, 38, 48 and 62at plane (101), (004), (200) and (204) respectively. The rutile peaks found at 54 (105) and 55 (211) [29-32]. The planes and peaks as referred to Joint Committee on Powder Diffraction Standards (JCPDS) database, JCPDS 21-1272 and JCPDS 21-1276 for anatase and rutile respectively. The catalyst was in the mixture phase and predominately by anatase. The mixture of amorphous and rutile was found to perform efficiently in pollutant degradation $[11,16,17,18]$. Yet, the mixture of rutile and anatase also found to degrade naproxen, carbamazepine [15] and clofibric acid [33]. The catalyst synthesized had the pHpzc of 6.7. This value for synthesized $\mathrm{TiO}_{2}$ can bevaried between 6.4 to 7.3 , which in the neutral condition $[11,15,18]$.

\subsection{Catalytic ozonation performance}

The concept of sludge ozonation is to break the sludge floc into smaller particle, followed by lysis of unit cell of microorganism that formed the sludge matrix.Both processes involve the disintegration and solubilisation. The extrapolymeric substances (EPS) is a complex high-molecular-weight polymer that responsible in agglomerating the microorganisms to form a larger floc [34]. Therefore, by breaking the sludge flocs, smaller particle produced which resulted in reduction of the TSS and also increased the soluble organic material in the supernatant.TheEPS also secreted by the microorganisms due to cellular activities, product of cell lysis, and also formed by the adsorbed organic materials in the wastewater $[35,36]$. The SCOD concentration was measured to evaluate the performance of activated sludge solubilisation. Since the EPS is a part of the sludge floc, the disintegration also can be evaluated by SCOD concentration.

The performance of sludge disintegration can be evaluated in the TSS reduction, as in Fig. 1(a) below. The same reduction of $4 \%$ at 30 minute of ozonation $\left(29.6 \mathrm{mgO}_{3} / \mathrm{gTSS}\right)$ was achieved for both processes. The reason why they have the same performance is that less or no formation of $\mathrm{OH} \bullet$ at this time to break the sludge flocs in $\mathrm{CO}$. The $\mathrm{OH} \bullet$ from ozone decomposition with aid of catalyst is believed to strong enough and start attacking the sludge flocsat dosage higher than $29.6 \mathrm{mg} / \mathrm{gTSS}$. The sludge flocs may compose of recalcitrant materials and too compact to be destructed with ozone even in the presenceof catalyst. The reduction was slower at ozone dose higher than $94.7 \mathrm{mg} / \mathrm{gTSS}$ (110 minute) onwards, and $0.48 \%$ reduction difference between both processes achieved at the end of the process.

In $\mathrm{CO}, 94.7 \mathrm{mgO}_{3} / \mathrm{gTSS}$ required to achieve $19 \%$ reduction of TSS. To obtain the same efficiency in non catalytic ozonation (NCO) system, it took higher ozone dose of 135.6 $\mathrm{mg} / \mathrm{gTSS}$ (150 minute). Further ozonation period as to increase the ozone doseshowed no increment in efficiency. This may be caused by the remaining hard-to-degrade particles and cannot be disintegrated with the supply ozone and available $\mathrm{OH} \cdot[37]$.

The SCOD resulted from solubilisation of EPS that bind the microorganism to form sludge floc, and from the inner cell [38]. Therefore disintegration of sludge floc and 
breakage of sludge cell caused the SCOD concentration to increase. The intracellular material of the cell also contributed to SCOD concentration in supernatant once it was disrupted. The performance of both processes is presents in Fig. 1(b) below. The CO reached maximum solubilisation $(19.38 \%)$ at 110 minute ozonation process and showed no increment after this period. Meanwhile at this contact time, the NCO achieved $10.14 \%$ and the maximum solubilisation was $13.98 \%$ at 150 minute. Higher solubilisation in CO system shows the present of more $\mathrm{OH} \bullet$ aided the ozone in disintegration and solubilisation of sludge flocs and cell breakage.

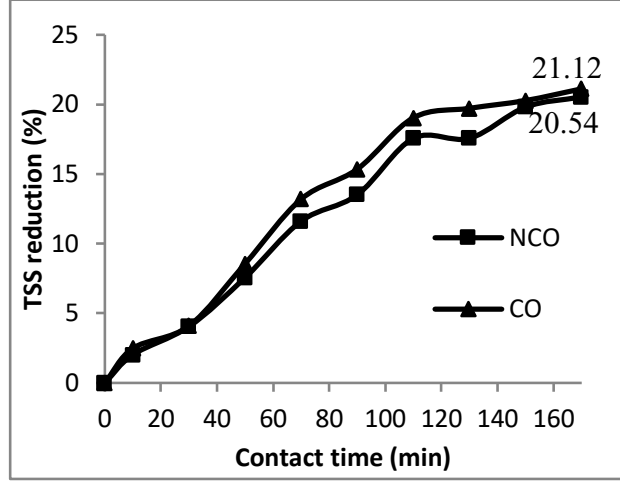

a)

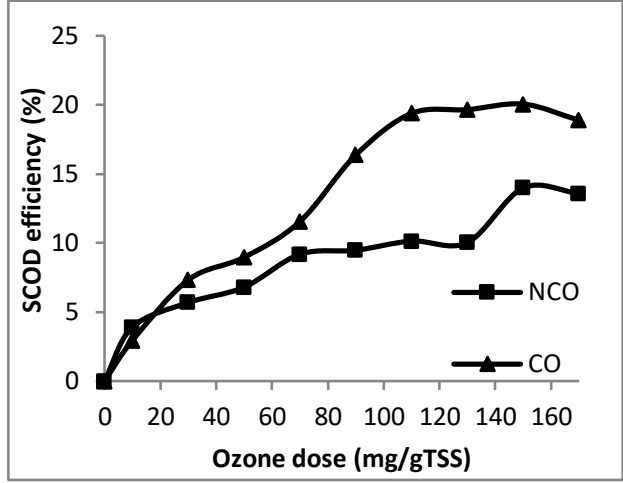

b)

Fig. 1. The TSS reduction (a) and SCOD solubilisation efficiency (b) for both processes.

During ozonation process, the EPS and sludge cell destruction released the deoxyribonucleic acid (DNA) and caused the sludge supernatant to be acidic. Production of fatty acid due to oxidation of higher to lower molecular weight organic matter also contributes to the reduction of supernatant $\mathrm{pH}$ [1]. Reduction of supernatant $\mathrm{pH}$ of 1.36 and 1.24 observed for CO and NCO system respectively. Chu et al.[39] and Dytczak et al.[40] also observed this changes in their processes.

\subsection{Effect of initial pH}

A graph of TSS reduction was plotted for the sludge disintegration efficiency observation, as in Fig. 2(a). At initial pH 7, the TSS reduced gradually and started to become slower at 110 minute to achieve maximum reduction of $21.12 \%$. The maximum reduction achieved was the best among other $\mathrm{pH}$. This is probably caused by the formation of $\mathrm{OH} \bullet$ by neutral hydroxyl on the catalyst surface that more effective at $\mathrm{pH}$ close to its $\mathrm{pH}_{\mathrm{PZC}}[11]$, and the synthesized $\mathrm{TiO}_{2}$ had the $\mathrm{pH}_{\mathrm{PZC}}$ of 6.7 , which is almost neutral.

An interesting trend at initial $\mathrm{pH}$ 9, where a rapid reduction observed at the early process, no reduction percentage increment until the $70^{\text {th }}$ minute, and the TSS reduced again to the maximum of $18 \%$ and no increment until the end of the process. Ozone decomposition occur faster at higher $\mathrm{pH}$ due to predominant of $\mathrm{OH}$ - as initiator [8] and caused the sludge disintegration to occur faster even at low ozone dose, due to more production of $\mathrm{OH} \bullet$ in the alkaline supernatant. This explained the rapid reduction of TSS at the early process. Onwards, released of DNA and lower molecular organic compound dropped the $\mathrm{pH}$ to 7.64, cause the $\mathrm{OH}$ - to unprevail and therefore, lesser production of $\mathrm{OH} \bullet$ to aid the disintegration efficiency, and reflected by the unchanged trend until the $70^{\text {th }}$ minute of ozonation. The reduction efficiency increased again was believed due to 
molecular attack of accumulation ozone and the decomposed ozone into $\mathrm{OH} \bullet$ on the sludge floc as the ozone dose increased.

No disintegration of sludge floc initially at $\mathrm{pH} 5$ due to less or maybe no $\mathrm{OH} \bullet$ present at lower $\mathrm{pH}$ [8]. The TSS reduction was observed after 30 minute of ozonation, when enough concentration of molecular ozone to disintegrate the sludge flocs at this contact time. The acidic solution made the catalyst surface to be positively charged, and the negative charge of sludge floc attracted and adsorbed on the catalyst.Instead of ozone decomposition reaction, the sludge floc is believed to oxidize on the catalyst surface by the attack of molecular ozone and $\mathrm{OH} \bullet$ from the bulk solution.

The performance at initial $\mathrm{pH} 5$ and 9 was found to unchanged at ozone dose higher than $82.6 \mathrm{mgO}_{3} / \mathrm{gTSS}$ (90 minute). However it can be seen that the reduction of TSS as initial $\mathrm{pH} 7$ still increasing until the end of the process, and concluded as the ideal $\mathrm{pH}$ for sludge disintegration at high ozone dose. However, in the point of economical view, it is not effective as more cost requires to supply high ozone dose for sludge floc disintegration. On the other side, additional of chemicals in the activated sludge for $\mathrm{pH}$ adjustment also need to be considered since additional of chemical may cause chaos in the microbiologic activities since the responsible bacteria was interrupted [41].

As for the solubilisation efficiency of organic matters, the performance is refers to Fig. 2(b) below. The solubilisation increased with ozone dose for all conditions of initial $\mathrm{pH}$. The higher the initial $\mathrm{pH}$, the higher the SCOD solubilised was observed. The efficiency achieved was $24.9 \%, 18.9 \%$ and $10.1 \%$ for initial $\mathrm{pH}$ of 9,7 and 5 respectively.CO enhances the disintegration of sludge floc, release more organic matter as the result of EPS and sludge cells destruction. By additional of $\mathrm{NaOH}$ during $\mathrm{pH}$ adjustment, the cell wall was disrupted, released organic matter from the microorganism and thus increased the SCOD concentration $[42,43]$. The SCOD efficiency in initial $\mathrm{pH} 9$ increased throughout the process, although the supernatant $\mathrm{pH}$ dropped to 7.64 after 10 minute of ozonation. This increment may be due to the breakage of sludge flocs and cells by $\mathrm{NaOH}$ during initial $\mathrm{pH}$ adjustment, followed by $\mathrm{OH} \bullet$ when the $\mathrm{CO}$ started. Therefore, smaller particles and organic materials was able to be continuously attacked by molecular ozone and $\mathrm{OH} \bullet$ from ozone decomposition throughout the process.

Between the three initial $\mathrm{pH}$ experiments, the initial $\mathrm{pH} 7$ was found to have the strongest correlation of SCOD solubilisation with TSS reduction when the $\mathrm{R}^{2}$ value is closer to 1 compared to other $\left(\mathrm{R}^{2}=0.961\right)$. Therefore, the SCOD solubilisation due to sludge floc disintegration was best occurred at initial $\mathrm{pH} 7$.

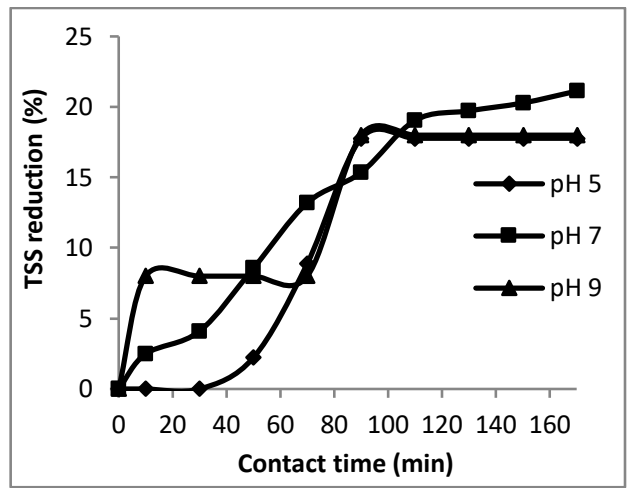

a)

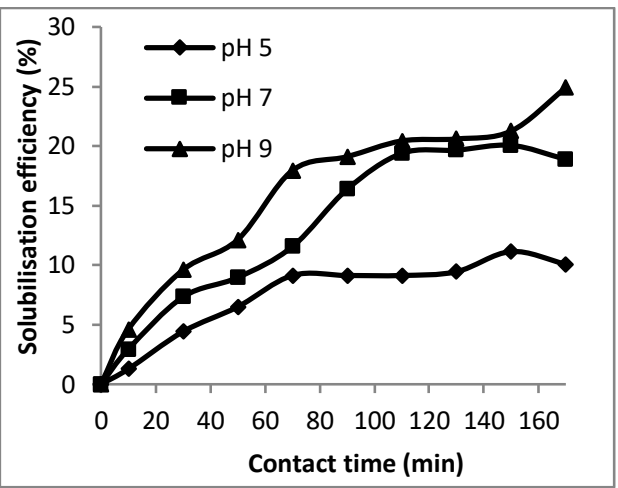

b)

Fig. 2. The TSS reduction (a) and SCOD solubilisation efficiency (b) for $\mathrm{CO}$ at different initial $\mathrm{pH}$. 


\subsection{Effect of catalyst dosage}

Catalyst dosage plays a role in the efficiency of a catalytic ozonation process. Theoretically, by increasing the catalyst dosage, the efficiency of a process also increased accordingly due to the availability of active sites for reaction to occur in decomposition of ozone into $\mathrm{OH} \bullet[44,45]$. Therefore, more $\mathrm{OH} \bullet$ would present to faster the reaction rate.

In investigating the effect of catalyst dosage, two different catalyst doses (100 and 200 $\mathrm{mgTiO}_{2} / \mathrm{gTSS}$ ) was manipulated to evaluate the performance efficiency. Using $100 \mathrm{mg} / \mathrm{g}$ catalyst found to be more efficient in activated sludge solubilisation compared to that 200 $\mathrm{mg} / \mathrm{g}$, with 25.2 and $17.1 \%$ respectively. Sludge floc disintegration was found to happen after 10 minute of the process, however ended with higher reduction of TSS $(30.4 \%)$. Oxidizing of suspended organic materials also occurred after 30 minute of ozonation process and oxidized up to $64 \%$ of the VSS. Although the higher dosage of $200 \mathrm{mg} / \mathrm{g}$ catalyst offers great ability to disintegrate sludge flocs and oxidize the organic matter initially, the efficiency was lower than that ozonation at lower catalyst dosage, with 21.9 and $33 \%$ of TSS and VSS reduction respectively. It is believed that in the initial process, more active sites available offers at higher $\mathrm{TiO}_{2}$ dosage. Even though more molecule ozone presents in bulk solution as increase of ozone dose, the amount of active sites on catalyst surface for ozone to be adsorbed and decomposed into $\mathrm{OH} \bullet$ only offered by a minimum amount of catalyst. Therefore, providing excess active sites by increasing the catalyst dosage do not enhance the process efficiency [17]. An ongoing experimental work using $150 \mathrm{mg}$ is conducted to observe if it is able to disintegrate and solubilise the activated sludge better than that the 100 and $200 \mathrm{mg}$ of $\mathrm{TiO}_{2}$.

\section{Conclusions}

The efficiency of sludge ozonation with synthesized $\mathrm{TiO}_{2}$ as catalyst was evaluated in this paper. With additional of $\mathrm{TiO}_{2}$ as catalyst, the ozone consumption in catalytic system was doubled than that the sole ozonation. From this research, some points can be summarised as follow:

1) The catalytic ozonation performed better in sludgesolubilistion. It was observed that the reduction of TSS was $21.12 \%$ and $20.54 \%$ for CO and NCO system, respectively. This small difference in TSS disintegration suggest that the present of catalyst does not improve much in disintegration, yet better in solubilisation of SCOD with $19.38 \%$ and $10.14 \%$ in $\mathrm{CO}$ and NCO respectively. The rubber processing activated sludge is a strong matrix that composed of recalcitrant compound.

2) Initial $\mathrm{pH} 7$ was the best condition to disintegrate and solubilise the activated sludge when the correlation of TSS reduction and SCOD solubilisation obtained was nearest to $1\left(\mathrm{R}^{2}=0.961\right)$. Although at initial $\mathrm{pH} 9$ was able to solubilised SCOD more, this better efficiency also may be attributed by the role of $\mathrm{NaOH}$ in $\mathrm{pH}$ adjustment that helped in activated sludge disintegration and solubilisation.

3) Lower catalyst dose of $100 \mathrm{mg} / \mathrm{g}$ disintegrate and solubilise the activated sludge better than $200 \mathrm{mg} / \mathrm{g} \mathrm{TiO}$. Although faster reaction in TSS and VSS reduction using $200 \mathrm{mg} / \mathrm{g} \mathrm{TiO}_{2}$ observed initially, the efficiency of these parameters and the SCOD was better at lower dose of catalyst at the end of the process.

From this research, it was suggested that the activated sludge ozonation with present of $\mathrm{TiO}_{2}$ as catalyst had positive effect in solubilisation. Further research to study the biodegradation on ozonated activated sludge is ongoing. 
The authors fully acknowledged the Malaysian Ministry of Higher Education (MOHE) for the research grant (FRGS 9003-00379),School of Environmental Engineering (UniMAP) for the facilities, Sustainable Engineering Research Cluster (UniMAP) for the XRDandShorubber(M) Sdn Bhd.

\section{References}

1. G. Zhang, J. Yang, H. Kiu, J. Zhang, Bioresour. Technol. 100, 1505-1509 (2009)

2. Y. Liu, Chemosphere 50, 1-7 (2003)

3. X. S. Guo, J. X. Liu, Y. S. Wei, L. Li, J. Environ. Sci. 19, 257-263 (2007)

4. C. Wu, G. Zhang, P. Zhang, C. C. Chang, Chem. Eng. J 240, 420-425 (2014)

5. P. Zhang, G. Zhang, W. Wang, Bioresour. Tech. 98, 207-210 (2007)

6. L. Chu, S. Yan, X. H. Xing, X. Sun, B. Jurcik, Water Res. 43, 1811-1822 (2009)

7. L. M. Dorfman, G. E. Adams, NSRDS-NBS-46 (1973)

8. B. Kasprzyk-Horden, M. Ziolek, J. Nawrocki, Appl. Catal., B: Env. 46, 639-669 (2003)

9. K. He, Y. M. Dong, Z. Li, L. Yin, A. M. Zhang, Y. C. Zheng, J. Hazard. Mater. 159, 587-592 (2008)

10. T. S. Ping, L. W. Hua, Z. J. Qing, C. C. Nan, Ozone Sci. Eng. 24, 117-122 (2002)

11. Y. Yang, J. Ma, Q. Qin, X. Zhai, J. Mol. Catal A: Chem. 267, 41-48 (2007)

12. S. P. Tong, W. P. Liu, W. H. Leng, Q. Q. Zhang, Chemosphere 50, 1359-1364 (2003)

13. Y. Dong, H. Zhao, Z. Wang, G. Wang, A. He, P. Jiang, B. Korean Chem. Soc., 33, 215-220 (2012)

14. K. J. Kim, K. D. Benkstein, J. Van De Lagemaat, A. J. Frank, Chem. Mater. 14, 10421047 (2002)

15. R. Rosal, A. Rodriquez, M. S. Gonzalo, E. Garcio-Calva, Appl. Catal. B: Env. 84, 4857 (2008)

16. Y. X. Yang, J. Ma, S. J. Wang, J. Zhang, 7th International Conference on Applied Electrostatic (ICAES) (2012)

17. Y. X. Yang, J. Ma, J. Zhang, S. J. Wang, Q. D. Qin, Ozone, Sci. Eng. 31, 45-52 (2009)

18. Y. Yang, H. Cao, P. Peng, H. Bo, J. Hazard. Mater. 279, 444-451 (2014)

19. M. J. Lee, Y. S. Kim, C. K. Yoo, J. H. Song, S. .J. Hwang, Environ. Technol. 31, 7-14 (2010)

20. M. J. Lee, T. H. Kim, G. Y. Yoo, B. K. Min, S. J. Hwang, KSCE J. of Civ. Eng. 14, 693-697 (2010)

21. J. Xiao, Y. Xie, H. Cao, Chemosphere, 121, 1-17 (2015)

22. J. Nawrocki, B. Kasprzyk-Hordern, Appl. Catal., B: Env. 99, 27-42 (2010)

23. N. Pugazthenthiran, P. Sathishkumar, S. Murugesan, S. Anandan, Chem. Eng. J. 168, 1227-1233 (2011)

24. A. Karami, JICS, 7, S154-S160 (2010)

25. H. Benhebal, M. Chain, T. Salmon, J. Geens, A. Leonard, S. D. Lambert, M. Crine, B. Heinrichs, Alex. Eng. J., 52, 517-523 (2013)

26. J. Zhang, J. Zhang, Y. Tian, N. Li, L. Kong, L. Sun, M. Yu, W. Zuo, Chem. Eng. J. (2016)

27. American Public Health Association. Standard Method for Examination of Water and Wastewater (1995)

28. S. T. Yan, L. B. Chu, X. H. Xing, A. F. Yu, X. L. Sun, B. Jurcik, Water Res. 43, 195$203(2009)$

29. S. Dain, Y. Wu, T. Sakai, Z. Du, H. Sakai, M. Abe, Nanoscale Res. Lett., 5, 1829-1835 (2010)

30. G. S. Devi, K. A. S. Kumar, K. S. Reddy, Part. Sci. Technol. 33, 219-223 (2015) 
31. E. Hosone, S. Fujihara, K. Kakiuchi, H. Imai, JACS 126, 7790-7791 (2004)

32. K. Thamaphat, P. Limsuwan, B. Ngotawornchai, Nat. Sci. 42, 357-361(2008)

33. R. Rosal, M. S. Gonzalo, A. Rodriguez, E. Garcia-Calvo, J. Hazard. Mater. 169, 411418 (2009)

34. J. Wingender, T. R. Neu, H. C. Flemming, Microbial extracellular polymeric substances: characterization, structures and function, 1-18 (1999)

35. Y. Liu, H. H. P. Fang, Crit. Rev. Env. Sci. Technol. 33, 237-273 (2003)

36. P. H. Nielsen, A. Jahn, Microbial extracellular polymeric substances: Characterization, structure and function, 49-72 (1999)

37. W. Saktaywin, H. Tsuno, H. Nagare, T. Soyama, J.. Weerapakkaroon, Water Res. 39, 902-910 (2005)

38. G. P. Sheng, H. Q. Yu, X. Y. Li, Biotechnol. Adv. 28, 882-894 (2010)

39. L. B. Chu, S. T. Yan, X. H. Xing, A. F. Yu, X. L. Sun, B. Jurcik, Chemosphere. 72, 205-215 (2008)

40. M. A. Dytczak, K. L. Londry, H. Siegrist, J. A. Oleszkiewicz, Water Res. 41, 543-550 (2007)

41. S. I. Perez-Elvira, P. Nieto Diez, F. Fdz-Polanco, Rev. Environ. Sci Bio. 5, 375-398 (2006)

42. M. J. Brown, J. N. Lester, Appl. Environ. Microbiol. 40, 179-185 (1980)

43. G. P. Sheng, H. Q. Yu, Z. Yu, Appl. Microbiol. Biotechnol. 67, 125- 130 (2005)

44. M. Muruganandham, J. J. Wu, Catal. Comm. 8, 668-672 (2007)

45. J. Park, H. Choi, J. Cho, Water Res. 38, 2285-2292 (2004) 